報 文

\title{
塩蔵中の大根ペクチンに及㴗す $\mathrm{Mg} \cdot \mathrm{Ca}$ 塩の影響と クリスプ性について
} 金子憲太郎* ・黑坂 光 江 ${ }^{*}$. 前田安彦**

\author{
Effects of $\mathrm{Mg}$ and Ca Salts on Changes of Pectic Substance \\ during Salting of Radish Root and Its Crisp Palatability
}

\author{
Kentaro Kaneko*, Mitsue KurosaKa* and Yasuhiko Maeda** \\ * Laboratory of Food Science, Koriyama Women's Junior College, \\ Kaisei, Koriyama-shi, Fukushima-Ken 963 \\ ** Department of Agricultural Chemistry, Utsunomiya University, \\ Mine-machi, Utsunomiya-shi, Tochigi-ken 320
}

The effects of $\mathrm{MgCl}_{2}$ and $\mathrm{CaSO}_{4}$ on the pectic substance during salting of radish root was studied. The results obtained were as follows: (1) The total amount of pectic substance in crude cell wall prepared from radish root was hardly changed during salting, though the ratio of hexametaphosphate soluble pectin (HXP) in the total pectin was markedly decreased and the ratio of hot water soluble pectin (HWP) in it was makedly increased. But $\mathrm{MgCl}_{2}$ and $\mathrm{CaSO}_{4}$ reduced the changes in the ratios of those pectin fractions. (2) The contents of $\mathrm{Mg}$ and $\mathrm{Ca}$ in the crude cell wall decreased during salting, while the addition of $\mathrm{MgCl}_{2}$ and $\mathrm{CaSO}_{4}$ reduced the decrease in this case. (3) The content of $\mathrm{Mg}$ or $\mathrm{Ca}$ in the HWP of the crude cell wall of radish root salted with sodium chloride containing $\mathrm{MgCl}_{2}$ or $\mathrm{CaSO}_{4}$ increased during salting, but the increment of the Ca content was less than that of $\mathrm{Mg}$. (4) The crispness or hardness of radish root salted with sodium chloride containing $\mathrm{MgCl}_{2}$ or $\mathrm{CaSO}_{4}$ increased during salting. Consequently it was presumed that the leak of $\mathrm{Mg}$ and $\mathrm{Ca}$ from radish root during salting resulted in the decrease of the HXP and the increase of the HWP, and furthermore the increased content of $\mathrm{Mg}$ or $\mathrm{Ca}$ in the HWP of the crude cell wall by salting with the mixed salt containing $\mathrm{MgCl}_{2}$ or $\mathrm{CaSO}_{4}$ might reform much cross-linkages within the HWP molecules to be changed to the HXP which hardened radish root during salting.

(Received Apr. 12, 1982)

\footnotetext{
カルシウム塩やマグネシウム塩は漬物のクリスプ性を 向上させることが知られているが1， その理由について は，不明な点が多い。

しかし、ペクチン質は野菜のテクスチャーと密接な関 連をもつことから²，そのことはぺクチン質がカルシウ ムやマグネシウムのような多価陽イオンにより何らかの
} 影響をうけたことに大きく依存すると思われる。 前報8)で，大根は塩蔵により，カルシウムとマグネシ
ウムが溶出し, それに伴って, 塩類結合型ペクチンタで あるーキサメタリン酸可溶性ペクチンが急減し，熱水可 溶性ぺクチンが急增することを明らかにした。また，そ れらの变化は, 塩蔵時に漬物工業で多用されている日本 専売公社輸入塩のらちの粉砕塩 (以下粉砕塩と略す) を 使用すると起りにくくなることから, 粉研塩中のカルシ ウム塩やマグネシウム塩は，ペクチン質の性状に可成の 影響を及ほし，そのことがクリスプ性を左右する一因に

* 郡山女子大学短期大学部食品化学研究室（T 963 福島県郡山市開成 3-25-2)

** 宇都宮大学農学部農芸化学科（T 320 杤木県宇都宮市峰町 350 ) 
なることを推察した。

従って，本報では大根の塩藏中に打けるぺクチン質 そ, マグネシウム塩・カルシウム塩との関係について検 討した結果，ぺクチン質の性状は，これらの塩類に左右 され，そのこととクリスプ性との間には密接な関連のあ ることをみいだしたので報告する。

\section{実 験 方 法}

\section{1. 供試大根}

神奈川県三浦市から出荷された 重さ：1.0〜1.4 kg, 長さ：28〜33 cm，太さ： $6.5 \sim 7.3 \mathrm{~cm}$ の練馬群理想大 根を供試した。

\section{2. 塩蒇方法}

塩蔵中のマグネシウム塩とカルシウム塩の影響をみる ために，塩蔵には，試薬特級の塩化ナトリウムを用い た。マグネシウム塩とカルシウム塩には，漬物に多用さ れる粉砕塩中のそれらが塩化マグネシウムと硫酸カル シウムであることから，試薬特級の塩化 マグネシウム $\left(\mathrm{MgCl}_{2} \cdot 6 \mathrm{H}_{2} \mathrm{O}\right)$ と硫酸カルシウム $\left(\mathrm{CaSO}_{4} \cdot 2 \mathrm{H}_{2} \mathrm{O}\right)$ を用 いた。なお，塩化マグネシウムには潮解性があるため， 硫酸デシケーターで乾燥したるのを用いた。

塩蔵には塩化ナトリウムの均一な浸透と部位による分 析值の差を少なくするために皮を除去した大根の上部約 $10 \mathrm{~cm}$ (最大直径 $6.5 \sim 7.3 \mathrm{~cm}$ )，3 kg 31 の塩化ナ トリウム溶液で液漬とし，重石は大根重量の $60 \%$ とし た（以下，塩化ナトリウム区と略す)。塭化マグネシウ ムは，塩化マグネシウムをマグネシウムの含量として塩 化ナトリウムの $0.2 \%$ 及び $0.5 \%$ (以下， $0.2 \%$ マグネ シウム区，0.5\%マグネシウム区と略す), 同様に硫酸カ ルシウムは、硫酸カルシウムがカルシウムの含量として， 塩化ナトリウムの $0.2 \%$ 及び $0.5 \%$ (以下， $0.2 \%$ カル シウム区，0.5\% カルシウム区と略す）になるように添 加し，いずれも塩化ナトリウム区と同様に大根を液漬し た。なお多量の大根を塩蔵する場合，塩蔵初期は低食塩 濃度であるため，最初の 3 日間は，大根の食塩が $5 \%$ 程 度になるようにするために，10\% 塩化ナトリウムの溶液 に漬け込み，その後，大根 $(2.8 \mathrm{~kg})$ の食塩を $10 \%$ 程度 にするために，大根と同量の $15 \%$ 塩化ナトリウム溶液 に漬けかえた。塩蔵は，11月上旬から 12 月上旬にかけ， 約 1 ケ月間, 室温 $\left(-5^{\circ} \mathrm{C} \sim 10^{\circ} \mathrm{C}\right)$ で行なった。

3. 熱水可溶性・ヘキサメタリン酸可溶性及び塩酸可 溶性の各ペクチン画分の定量

前報泉に準じた。

\section{4. 粗細胞壁の調製}

前報致に準した。

5. 粗細胞壁のカルシウムとマグネシウムの定量

前報8) に従い，日立 207 型原子吸光分光光度計で測定 した。

6. 熱水可溶性ペクチンのカルシウムとマグネシウム の定量

粗細胞壁（1２ g) から $500 \mathrm{ml}$ のイオン交換蒸留水 で煮沸抽出（1 h）される 画分を透析チュープ（ビスキ ング社製，シームレス・セルローズ・チニービング）で 透析 (24 hs) ・減生濃縮 $\left(40^{\circ} \mathrm{C}\right.$ 以下) 後に $80 \%$ エチル アルコール髥度としたときに生成する 沈澱物を 550 $600^{\circ} \mathrm{C}$ で死化したものを分析試料とし，前報8に彷い， 日立 207 型原子吸光分光光度計で測定した。

\section{7.クリスプ性の評価}

前報》) に従ってテクスチェロメーター (全研製, GTX2)で測定した“硬さ”により評価した。なお，測定值 は 10 検体の平均值であらわした。

\section{実験結果及び考察}

1. 熱水可溶性・ヘキサメタリン酸可溶性及び塩酸可 溶性ペクチンの変化

塩化ナトリウム区の大根粗細胞壁のペクチン総量にた いする熱水可溶性・—キサメタリン酸可溶性・塩酸可溶 性ペクチンの割合を Fig. 1，0.2\%マグネシウム区のそ れを Fig. 2，0.5\% マグネシウム区のそれを Fig. 3， $0.2 \%$ カルシウム区のそれを Fig. 4, 0.5\% カルシウム 区のそれを Fig. 5 に示した。

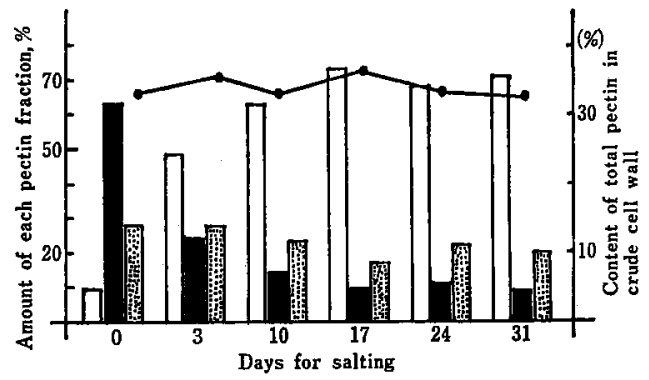

Fig. 1 Changes of the composition of pectic substances in the crude cell wall preparation from radish root during salting with sodium chloride

--): Total pectin. $\square$ : Hot water soluble pectin. $0.4 \%$ hexametaphosphate soluble pectin. $\square=0.05 \mathrm{~N}-\mathrm{HCl}$ soluble pectin. 


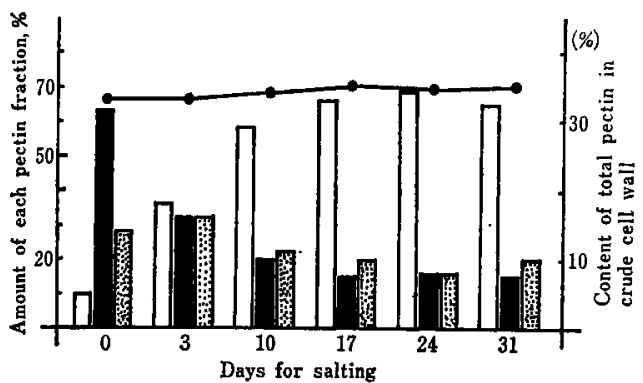

Fig. 2 Changes of the composition of pectic substances soluble in hot water, $0.4 \%$ hexametaphosphate and $0.05 \mathrm{~N}-\mathrm{HCl}$, respectively, in the crude cell wall preparation from radish root during salting with sodium chloride containing $0.2 \% \mathrm{Mg}$

Symboles were same as those in Fig. 1 .

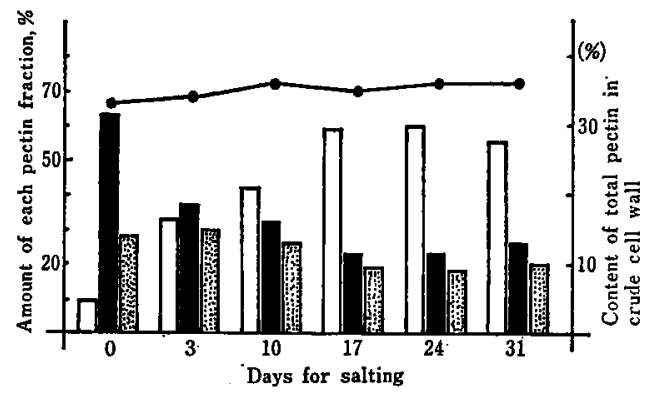

Fig. 3 Changes of the composition of pectic substances soluble in hot water, $0.4 \%$ hexametaphosphate and $0.05 \mathrm{~N}-\mathrm{HCl}$, respectively, in the crude cell wall preparation from radish root during salting with sodium chloride containing $0.5 \% \mathrm{Mg}$

Symboles were same as those in Fig. 1.

いずれの区の大根む塩蔵によって，ペクチンの総量は ほとんど変化しなかったが，塩蔵 17 日頃までの間に一 キサメタリン酸可溶性ベクチンの顕著な減少と，熱水可 溶性べクチンの顕著な増加が起り，それ以後はほとんぞ 变動しなかった。また，塩酸可溶性べクチンは塩葴期間 中ほほとんど変動しない上うに思えた。この現象は，塩 化ナトリウム区の大根が最を顕著であり， $0.5 \%$ カルシ ウム区のものが最も少なかった。

すなわち, べタチン総量にたいする熱水可溶性，一キ サメタリン酸可溶性，塩酸可溶性 ペクチンの割合は，

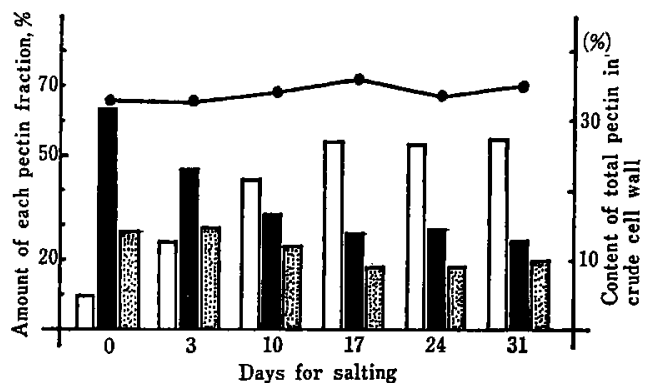

Fig. 4 Changes of the composition of pectic substances soluble in hot water, $0.4 \%$ hexametaphosphate and $0.05 \mathrm{~N}-\mathrm{HCl}$, respectively, in the crude cell wall preparation from radish root during salting with sodium chloride containing $0.2 \% \mathrm{Ca}$

Symboles were same as those in Fig. 1 .

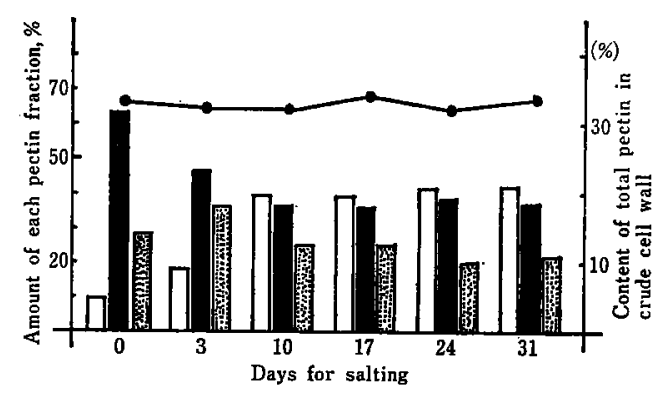

Fig. 5 Changes of the composition of pectic substances soluble in hot water, $0.4 \%$ hexametaphosphate and $0.05 \mathrm{~N}-\mathrm{HCl}$, respectively, in the crude cell wall preparation from radish root during salting with sodium chloride containing $0.5 \% \mathrm{Ca}$

Symboles were same as those in Fig. 1 .

$10: 63: 27$ であったが, 塩藏 31 日目におけるそれらの 割合柱, 塩化ナトリウム区 $=71: 9: 20,0.2 \%$ マグネシ ウム区 $=65: 15: 20,0.5 \%$ マグネシウム区 $=55: 26$ : $19,0.2 \%$ カルシウム区 $=55: 25: 20,0.5 \%$ カルシウ ム区 $=42: 37: 21$ であり，一キサメタリン酸可溶性 ぺ クチンの割合は, $0.5 \%$ カルシウム区 $>0.2 \%$ カルシウ 厶区 $\fallingdotseq 0.5 \%$ マグネシウム区，0.2\% マグネシウム区>

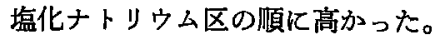

以上の結果，大根の粗細胞壁ぺクチン総量は，程蔵に よって変化しないが，ペクチン総量にたいするへキサメ 
タリン酸可溶性ペクチンの割合の減少と熱水可溶性ぺタ チンの割合の増加が顕著に起った。しかし，マグネシウ ム塩やカルシウム塩にはそのことの阻止作用があり，カ ルシウム塩にその作用の強いことが明らかになった。

従って，粉磼塩で塩蔵した大根の粗細胞壁ペクチンが 精製塩で塩蔵したものよりへキサメタリン酸可溶性ペタ チンの割合の高いことは8，粉砤塩中の塩化マグネシウ ムと硫酸カルシウムの作用によるるのであり, 特に硫酸 カルシウムに依存するところの大きいことが明らかにな った。

\section{2. マグネシウム及びカルシウム含量の変化}

(1) 粗細胞壁中での変化について

前報》で，大根の塩藏中に起る、へキサメタリン酸可溶 性ペクチンの減少は粗細胞壁のマグネシウムとカルシウ ムの溶出に依存することを推察した。従って，塩化マグ ネシウムないし硫酸カルシウムを添加した塩化ナトリウ ムで塩蔵した大根にへキサメタリン酸可溶性ペクチンの 多いこと (Fig. 1〜Fig. 5) は，とれらの塩類が塩藏中， 大根炕とりこまれ，粗細胞壁から溶出するマグネシウム とカルシウムを補った結果であると考えられる。そこ で，塩蔵中における粗細胞壁のマグネシウムとカルシウ ム含量の变化について検討した。

Fig. 6 にマグネシウム含量の変化を示した。大根粗 細胞壁のマグネシウムは約 $185 \mathrm{mg} \%$ でったが，塩化 ナトリゥム区と $0.2 \%, 0.5 \%$ カルシウム区のそれは塩 蔵によって明らかに減少した。しかし，それは塩蔵寓10
日目頃までに起り，それ以後はほぼ一定であった。塩藏 31 日目に㧍けるこれらの区のマグネシウム含量は，ほと んど同量であり，大根粗細胞壁の含量の $25 \%$ 程度に減 少していた。

$0.2 \%$ 及び $0.5 \%$ マグネシウム区のるののマグネシウ 厶含量は，塩蔵 10 日目頃宋で若干隇少する傾向にあっ たが，それ以後は，堌加する傾向にあった。すなわち， 壏蔵 10 日目のマグネシウムは 大根粗細胞壁の含量にた いして，0.2\% マグネシウム区のるのが約 $48 \%, 0.5 \%$ マグネシウム区のものが約 $90 \%$ であったが，塩蔵 31 日 目にはそれぞれ約 1.1 倍，約 2.0 倍に増加していた。

Fig. 7 に粗細胞壁のカルシウム合量の変化を示した。 塩化ナトリゥム区と $0.2 \% ， 0.5 \%$ マグネシウム区のそ れは，塩化ナトリウム区及び $0.2 \% ， 0.5 \%$ カルシウム 区におけるマグネシウムの場合とほとんど同様な傾向に あった。すなわち，大根粗細胞壁のカルシウムは約 560 $\mathrm{mg} \%$ であったが塩蔵 10 日目頃までに減少し，それ以 後はほとんど变化がなく，塩藏 31 日目の含量は，大根 粗細胞壁のそれの $43 \sim 49 \%$ であった。

また， $0.2 \%$ カルシウム区のカルシウムは塩蔵 3 日目 に減少し，それ以後はほほ一定であるょうに思えた。し かし， $0.5 \%$ カルシウム区のそれは塩蔵 3 日目に增加後, 17 日目までは減少し，それ以後はほほ一定であった。

塩蔵 31 日目のカルシウム含量は, $0.2 \%$ カルシウム 区のものが大根粗細胞壁のそれの約 $82 \%, 0.5 \%$ カルシ ウム区のものは，大根粗細胞壁のそれとほほ同量であっ

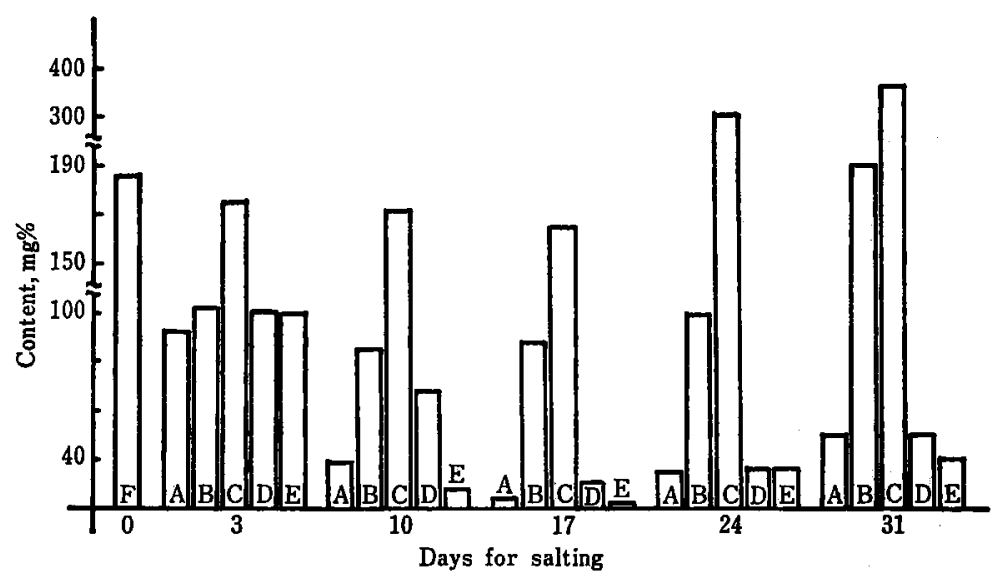

Fig. 6 Changes in content of $\mathrm{Mg}$ in crude cell wall from radish root during salting F: Fresh radish root. A: Salted with sodium chloride. B: Salted with sodium chloride containing $0.2 \% \mathrm{Mg}$. C: Salted with sodium chloride containing $0.5 \% \mathrm{Mg}$. D: Salted with sodium chloride containing $0.2 \%$ Ca. E: Salted with sodium chloride containing $0.5 \% \mathrm{Ca}$. 


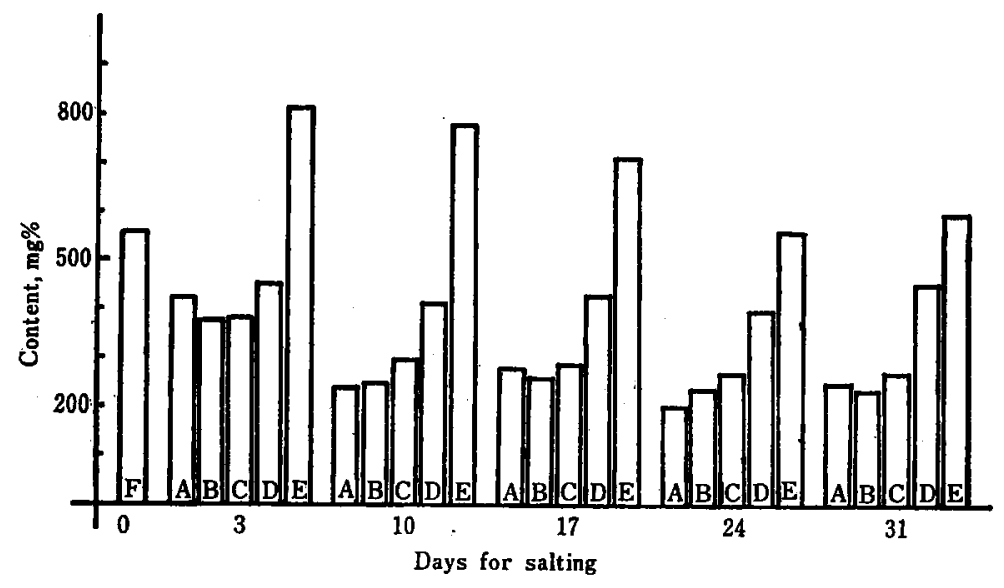

Fig. 7 Changes in content of $\mathrm{Ca}$ in crude cell wall from radish root during salting Symboles were same as those in Fig. 6.

た。なお，0.5\% カルシウム区におけるカルシウム含量 の增減は，0.2\% カルシウム区においてすごく僅かでは あるが似たような現象が起るように思えることからこ のことは 3 日目以後大根の食篮浱度が $10 \%$ になるよう な盐化ナトリゥム溶液に清けかえたことに依存する食塩 の浸透圧の変化及び粗細胞壁成分とカルシウムの結合力 に依存すると思われる。以上の結果, 塩化マグネシウム と硫酸カルシウムは大根によりこまれ，塩蔵中に起る粗 細胞壁のマグネシウムとカルシウムの溶出を補うことが 明らかになった。従って，これらの塭頑を添加した塩化 ナトリウムで壏蔵した大根に一キサメタリン酸可溶性ぺ クチンの多い (Fig. 1〜Fig. 5) ことは，一キメタリン 酸可溶性ペクチンが，カルシウムやマグネシウムなどと 結合した塩類結合型のベクチンタであることから，これ らの塩類が塩藏中に起る大根粗細胞壁のマグネシウムの 溶出を補った結果であるといえる。なお，マダネシウム 添加区におけるマグネシウム性塩蔵 10 日目以後に增加 するがカルシウム添加区におけるカルシウムがほとんど 变動を示さないことはマグネシウム区・カルシウム区に おけるそれらの多価陽イオンの添加量が同じであること から，これらの多価陽イオンと粗細胞壁成分の結合しや すさに一因があると思われる。

（2）熱水可溶性ベクチン中での变化について

塩化マグネシウムないし硫酸カルシウムを添加した塩 化ナトリウムで塩蔵した大根の粗細胞壁に一キサメタリ ン酸可溶性べタチンの多いことは, これらの塩類が塩藏 中，粗細胞壁にとりこまれることからそそれら塩類のイ オンが熱水可溶性ペクチンと結合してへキサメタリン酸

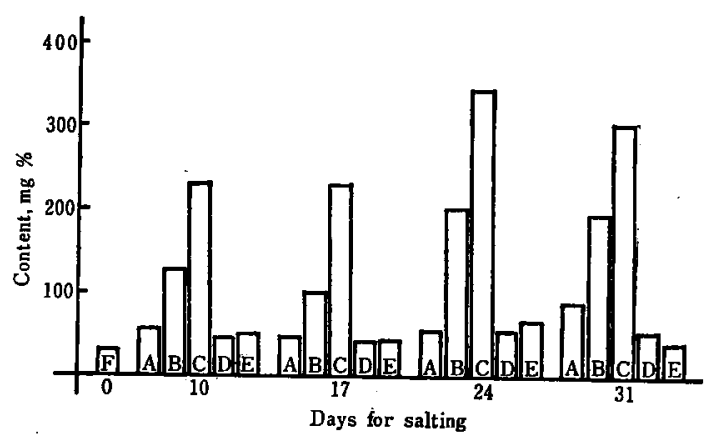

Fig. 8 Changes in content of $\mathrm{Mg}$ in hot water soluble pectin from crude cell wall of radish root during salting Symboles were same as those in Fig. 6.

可溶性ペクチンを再生すると思われる。従って，熱水可 溶性ペクチン中のマグネシウムとカルシウムの含量を分 析して検討した。

Fig. 8 にマグネシウム含量の变化を示した。塩化ナ トリゥム区と $0.2 \%, 0.5 \%$ カルシウム区の含量は塩蔵 期間安通して大幅な変化をしなかった。すなわち，大根 粗細胞壁の 熱水可溶性 ペクチン中のマグネシウムは 約 $35 \mathrm{mg} \%$ であり，塩蔵後 31 日には塩化ナトリウム区が 䄪 $89 \mathrm{mg} \% ， 0.2 \%$ カルシウム区が約 $54 \mathrm{mg} \%, 0.5 \%$ カルシウム区が約 $41 \mathrm{mg} \%$ であった。

しかし，0.2\% 及び 0.5\% マグネシウム区のそ礼は顕 著に増加しており，塩蔵 10 日目は $0.2 \%$ マグネシウム 区が約 $127 \mathrm{mg} \%, 0.5 \%$ マグネシウム区が約 $231 \mathrm{mg}$ $\%$ ，塩藏 31 日目にはそれぞれ約 $195 \mathrm{mg} \%$ ， $305 \mathrm{mg}$ 


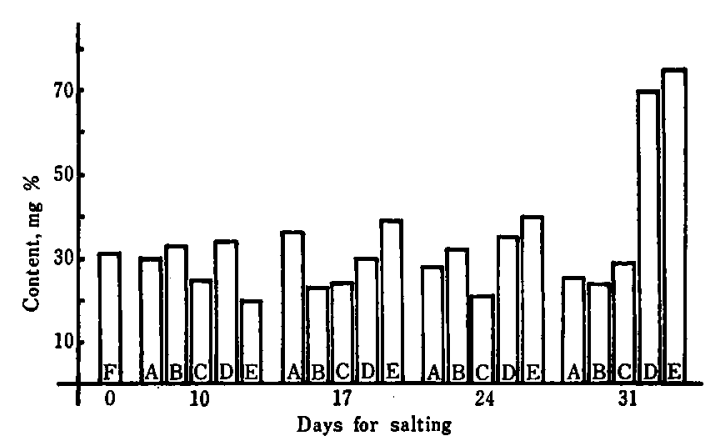

Fig. 9 Changes in content of $\mathrm{Ca}$ in hot water soluble pectin from crude cell wall of radish root during salting

Symboles were same as those in Fig. 6.

\%であり，人キサメタリン酸可溶性ペクチンの多い0.5 \%マグネシウム区にその量が最る多かった。従って, これらのことからマグネシウムは熱水可溶性べクチンと 結合することが明らかになった。

このことは，マダネシウムイオンと熱水可溶性ベクチ ンが結合した結果，それの分子間架橋が進み51，ベクチ ン分子の增大とそれに伴う熱水可溶性ペクチンの不溶 化，すな⿰ち， 一キサメタリン酸可溶性ペクチンへの移 行が起ると考えられる。

Fig. 9 にカルシウム含量の変化を示した。マグネシ ウムの場合とことなっており，カルシウムは $20 \sim 70 \mathrm{mg}$ \% の範囲にあり， $0.2 \%$ 及び $0.5 \%$ カルシウム区にお けるカルシウムの增加は顕著でなかった。

$0.2 \%$ 及び $0.5 \%$ カルシウム区のカルシウムの増减が 僅かであることは，マグネシウムが $0.2 \%$ 及び $0.5 \%$ マ グネシウム区で顕著に增加していることとくらべて大き なちがいであった。しかし，てのことはカルシウムが熱 水可溶性ペクチンと結合しないことではなく，カルシウ ムイオンもマグネシウムイオンと同様にペクチン分子と 架橋結合51 をすること，0.2\% 及び $0.5 \%$ カルシウム区 における 粗細胞壁のカルシウム含量が他の区より多い (Fig. 7.) こと及びペクチンにたいする一キサメタリン 酸可溶性へクチンの割合は， $0.5 \%$ カルシウム区>0.2\% カルシウム区 $\fallingdotseq 0.5 \%$ マグネシウム区>0.2\% マグネシ ウム区の順 (Fig. 1〜Fig. 5) である゙ことから考えると， カルシウムと結合した熱水可溶性べクチンはマグネシウ ムと結合したものよりも熱水に不溶化し，その結果一キ サメタリン酸可溶性ペクチンに移行する量が多くなった と考えることができる。従って，カルシウム塩はマグネ シウム塩よりも，熱水可溶性ペクチンを一キサメタリン
酸可溶性べタチンに移行させやすく，そのために，カル シウム塩を添加した塩化ナトリウムで塩蔵した大根法, マグネシウム塩を添加したものよりも一キサメタリン酸 可溶性ペクチンが多い（Fig. 2〜Fig. 5）と考えられる。 3. クリスプ性について

ヘキサメタリン酸可溶性ペクチンの割合に顕著な特徵 のみられた塩化ナトリウム区，0.5\%，マグネシウム区， $0.5 \%$ カルシウム区の塩蔵中におけるクリスブ性の変化 をテクスチニロメーターによる: “硬さ”で検討した結 果范, Fig. 10 に示した。なお, 塩藏初期は塩化ナトリ ウムの浸逶が不充分であり，そのために“硬さ”の測 定値に個体差が大きくなると考えたので，それの測定は 塩蔵 10 日以後に開始した。

塩蔵 10 日目の大根の“硬さ”は，塩化ナトリウム区 のものが約 $16 \mathrm{~kg} / \mathrm{V}$ で最も硬く， $0.5 \%$ カルシウム区 と $0.5 \%$ マグネシウム区のものがほ活同程度の約 $14 \mathrm{~kg}$ / V゙あった。

塩化ナトリウム区の大根の“硬さ”は塩藏中にほと んど変化しなかったけれど， $0.5 \%$ マグネシウム区と $0.5 \%$ カルシウム区の大根の“硬さ”は，塩藏中に潮 次增加してゆき，塩蔵 31 日目には $0.5 \%$ カルシウム区 (約 $19 \mathrm{~kg} / \mathrm{V})>0.5 \%$ マグネシウム区（約 $17 \mathrm{~kg} / \mathrm{V}$ ) > 塩化ナトリウム区（約 $16 \mathrm{~kg} / \mathrm{V}$ ) の順で硬かった。

$0.5 \%$ マダネシウムと $0.5 \%$ カルシウム区の大根の “硬さ”が漸次増加することは，0.5\% マグネシウム 区の 粗細胞壁マグネシウムが塩蔵 7 日以後漸次 増加し (Fig. 6)，同様に 0.5\% カルシウム区のカルシウムは塩 蔵 24 日以後ほほ一定になる (Fig. 7) ことや，ベクチ

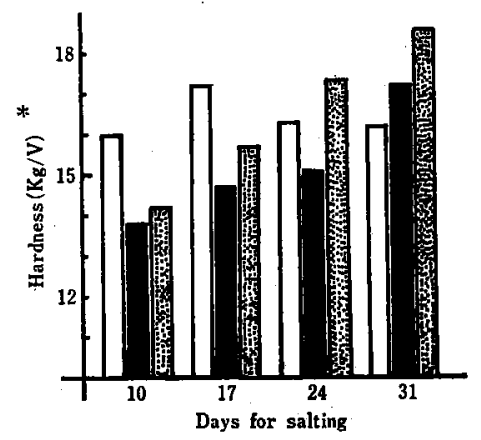

Fig. 10 Changes in the hardness of radish root during salting

*: Texturometer unit. $\square$ : Salted with sodium chloride $\square$ : Salted with sodium chloride containing $0.5 \% \mathrm{Mg}_{\mathrm{R}}$ : Salted with sodium chloride containing $0.5 \% \mathrm{Ca}$ 
ンにたいする熱水可溶性・人キサメタリン酸可溶性及び 塩酸可溶性ペクチンの割合が塩蔵 17 日目以後ほほ一定 になる (Fig. 3, Fig. 5) ことなどから考えて, マグネ シウムやカルシウムによるペクチン分子の架橋結合に依 存するベクチンの分子量増大や分子のひろがりの縮小が

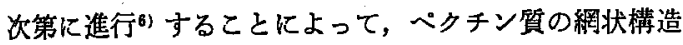
が緸密化してゆき，その結果, “硬さ”の增加が起る むのと思われる。

また， $0.5 \%$ カルシウム区の大根が $0.5 \%$ マグネシウ ム区のものより，“硬い”ことは，人キサメタリン酸 可溶性ベクチンの量が前者に多い (Fig. 3, Fig. 5) こ とから考光て，カルシウム塩はマグネシウム塩よりるぺ クチンに分子量の增大や分子のひろがりの縮小を起しゃ すいと思われる。

以上の結果から，漬物のクリスプ性がマグネシウム鳁

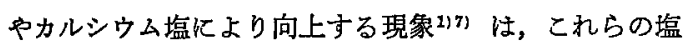
類が漬物に浸透した結果，それらの多価陽イオン金属と ベクチン質が結合し，分子量の増大や分子のひろがりの 縮小に依存するペクチン質の網状構造の緻密化が生ずる ために起ると考えられる。

\section{要 約}

漬物のクリスプ性はマグネシウム塩やカルシウム塩に より向上することが現象的に明らかになっている。しか し，その理由については不明な点が多い。

前報 ${ }^{a)}$ の結果から,そのことは，それらの塩類とべクチ ン質の関係に依存するところが大きいと推察された。從 って，本報では大根の塩蔵中におけるペクチン質とマグ ネシウム塩・カルシウム塩の関係について検討し，併せ てクリスブ性との関連性について考察した。

（1）大根の粗細胞壁ベクチンにたいする熱水可溶性， ヘキサメタリン酸可溶性, 塩酸可溶性ペクチンの割合 は, $10: 63: 27$ であったが塩蔵によってへキサメタリ ン酸可溶性べタチンから熱水可溶性ベクチンへの移行が 顕著に起り，塩蔵 31 日目の割合は 71:9:20であった。 けれどむ，ベチン総量はほとんど変化していなか。 た。

しかし，塩化マグネシウムと硫酸カルシウムは，この 変化を阻止し, 後者にその作用が強かった。

(2) 大根粗細胞壁のマグネシウムとカルシウムは，そ れぞれ約 $185 \mathrm{mg} \%$, 約 $560 \mathrm{mg} \%$ であったが, 塩蔵 31 日目にはマグネシウムが約 $25 \%$ ，カルシウムが䄪 $45 \%$
に減少し, 一キサメタリン酸可溶性ペクチンも少なかっ た。しかし，塩化マグネシウムないし硫酸カルシウムを 添加した塩化ナトリウムで塭蔵したものは，それぞれマ グネシウム，カルシウムが顕著に多く，一キサメタリン 酸可溶性べクチンも多かった。從って，塩蔵によるへキ サメタリン酸可溶性ぺクチンの減少は大根からマグネシ ウムやカルシウムのような多価陽イオンの溶出に起因す ると考えた。

(3) 塩化マグネシウムを添加した塩化ナトリウムで塩 蔵した大根の粗細胞壁から抽出した熱水可溶性ぺクチン のマグネシウムと硫酸カルシウムを添加して塩蔵したそ れのカルシウムは塩蔵によって生成した熱水可溶性ぺク チンと結合し, 分子量の増大などを引き起した結果, 一 キサメタリン酸可溶性ペクチンを再生すると考えた。ま た， ヘキサメタリン酸可溶性ベタチンの再生力はマグネ シウムよりカルシウムが強く, その結果, 硫酸カルシウ ム炎添加した塩化ナトリウムで壏蔵した大根は, 塩化マ グネシウムを添加して塩蔵したものよりもへキサメタリ ン酸可溶性ペクチンが多いと考えた。

（4）塩蔵中におけるクリスブ性の变化をテクスチニロ メーターによる “硬さ”で検討したところ, 硫酸カル シウム, 塩化マグネシウムともに“硬さ”穵増加させ たが，前者にその作用が強かった。このことは，硫酸力 ルシウムを添加した塩化ナトリウムで塩蔵した大根は塩

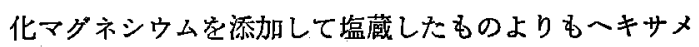
タリン酸可溶性ペクチンの多いことから,カルシウムは, マグネシウムよりもペクチンに架橋結合の増加による網 状構造の緻密化を起しやすく，それ結果，マグネシウム よりも“硬さ”の増加にたいして効果があると考えた。

\section{文献}

1）食品研究社編：実際的清物加工法（食品研究社）, p. 155 (1966).

2) 永沢 信：総合多糖類科学下（原田篤也 -三畸旭 編)，p. 501, 講談社 (1974).

3）金子憲太郎 - 黒坂光江 - 前田安彦：日食工誌, 29, 611 (1982).

4) 川端晶子・澤山 茂: 栄養学雑誌, 31, 32(1973).

5) 川端晶子・澤山茂：栄養と食糃，28,17(1975).

6) 川端晶子・澤山茂・鎌田俊雄：農化， 53，61 (1979).

7）芥田三郎：食の科学，32，43 (1976). (昭和 57 年 4 月 12 日受理) 